\title{
Risking It All: Irregular Migration from Ghana through Libya to Europe and Its Impact on the Left-Behind Family Members
}

\author{
Steve Tonah, Emmanuel Codjoe
}

\section{Introduction: Changing Migration Trends in Ghana}

Ghana has been a major migrant-producing country for several decades. Indeed, with the exception of the period immediately preceding and after independence in 1957, many more migrants have left than have arrived in the country. The dwindling economic fortunes of the post-independence period as well as the unstable political situation in that period quickly turned the country from an immigrant-receiving into a major emigrant-producing country (Agyeman/Setrana 2014; Anarfi/OfosuMensah/Ababio 2018). While the vast majority of these emigrants moved to the neighbouring West African countries, those who could afford it moved to new destinations in Europe, North America and Southern Africa (Anarfi/Kwankye 2003; Adepoju 2005, 2010). These mass migrations of Ghanaians abroad have resulted in the establishment of large diaspora settlements in several countries in Africa as well as overseas (Manuh 2005; Arthur 2008; Tonah 2007; Awumbila et al. 2011).

Despite the return to democratic rule in 1992, the quest among many Ghanaians to move abroad has not abated. Whilst it has been relatively easy for Ghanaians to 
travel within the African continent due to the absence of visa restrictions, many industrialised countries have imposed visa restrictions limiting the entry of Ghanaians into their territories. This has resulted in the emergence of a booming illicit market for fake visas, passport and document fraud, insurance and financial guarantee scams and many other illicit arrangements (Codjoe 2017).

This paper examines the irregular migration of Ghanaians to Libya and Europe using the land and sea routes, respectively, during the reign of Muammar Gadhafi and since his overthrow in 2012. The paper focuses on emigrants from the Nkoranza area in Central Ghana. The area is noted not only for the high number of migrants abroad but also for irregular migration to Libya and Europe across the Sahara. The paper first provides a brief description of the Bono people of the Nkoranza District, it then presents an overview of the methods used in data collection as well as the theoretical perspectives underpinning this paper. In subsequent sections the paper provides a detailed description of the nature of migration from the Nkoranza area to Libya and Europe, expatiating on the complex process of the migration journey and the lived experiences of individual returned migrants. Finally, the paper analyses the impact of irregular migration on the extended family left-behind as well as on the returned migrants themselves.

\section{The Study Population and Methods}

The study was carried out in the administrative districts of Nkoranza South and North in Central Ghana. These two districts are similar in many ways. They share a common language, culture and socio-economic characteristics. The area is dominated by the Bono people who constitute about 60 per cent of the population with the remaining being migrants from northern Ghana, mainly Dagaaba, Konkomba and Kasena people. The Nkoranza area with a combined population of about 170,000 people in 2010 is largely rural with a few urban settlements including the capital towns of Nkoranza $(34,498)$ and Busunya $(5,424)$. The area has a youthful population with about 40 per cent of the population being under 15 years and another 43 per cent being between 15 and 60 years. Most of the inhabitants $(86.9$ per cent) are farmers and forestry workers with the rest engaged in trading, craft-making, and other technical and professional jobs. Cashew cultivation is the main cash crop grown in the area (GSS 2014). Households are either of the nuclear or the extended type with an average household size of five persons per household. Most households are monogamous although polygynous ones are very common (GSS 2014; Codjoe 2017).

Research work for this paper was done in two separate phases by the authors. The first fieldwork was done between February and May 2017 in the Nkoranza North District and involved a mixed method approach. For the quantitative aspect, questionnaires were administered to 100 returned irregular migrants and another 100 family members of returned migrants who had used the land and sea routes to Libya 
and Europe, respectively. The respondents were randomly selected from a list of 224 members provided by the Borga Association of returned irregular migrants and the questionnaires were administered to 21 persons in Kranka, 36 in Busunya, 13 from Yefri, 7 from Fiema, 8 from Buabeng and 15 from Dromankese. ${ }^{1}$ This was then followed by in-depth interviews ${ }^{2}$ of 33 persons purposively selected from the members and leadership of the Borga Association, public sector officials, staff of NGOs, traditional and community leaders. The families of the returned migrants were selected from among those who were spouses (mainly wives), parents, siblings and children of irregular migrants. A follow up fieldwork was done by the second author in July 2018 in the Nkoranza South District. This was largely a qualitative research and it involved a detailed study of the daily lives and experiences of 15 purposively selected returned irregular migrants and their family members. In-depth interviews were also held in Accra with two persons who worked as teachers in Libya between 1984 and 1987.

The quantitative data was analysed using the SPSS Version 21 while the qualitative data was analysed according to themes. Besides capturing the sociodemographic characteristics of the returned migrants and their family members, the quantitative data provided information on several aspects of the nature and scope of irregular migration (such as the decision to migrate, contributions of spouses and relatives, length of stay abroad, regularity and forms of communication with families left behind, type and frequency of remittances etc.) while the qualitative data provided detailed experiences of individual migrants before, during and upon their return from abroad. It also captured the emotional, spiritual and psychological experiences of spouses and family members left behind which could not be captured in a questionnaire.

From a theoretical perspective this paper is underpinned by the "culture of migration" theory. The theory describes a society characterised by a very high rate of migration, such that migration becomes habitual, a part of normal life or a people's behavioural repertoire. In such a society the aspiration to migrate is transmitted across generations and among relatives, neighbours, friends and people through their social networks (see Kandel/Massey 2002; Massey 2012; Fiedler 2018). The culture of migration thus strongly influences the individual and household decision to migrate, as well as how individuals and groups assess the social structural conditions in which they live. The Bono people of Central Ghana, just as other groups in

\footnotetext{
1 Only 11 out of the 100 irregular returned migrants were deported. The rest returned voluntarily, mainly as a result of the political violence in Libya, economic difficulties, illness and wanting to be united with their family. The length of stay of the returned migrants in Libya and/or Europe varied from 3 months to 11 years. Some of the migrants returned prior to the Libyan Civil War in 2011 while others came thereafter.

2 The in-depth interviews were held in the respondents' homes or working places and lasted between 45 minutes and one hour per person. They mainly involved asking a series of prepared questions that sought information on their knowledge and lived experiences with irregular migration in the Nkoranza area. Some respondents were contacted a number of times for further information and confirmation of information received from elsewhere.
} 
West Africa, have been associated with the tradition of moving abroad in search of greener pastures over several decades. ${ }^{3}$

\section{Ghanaian Migration to Libya}

Ghanaian migration to Libya can be traced back to the early 1980s when as a result of political instability, economic mismanagement, adverse weather conditions and sanctions by foreign governments the nation's economy crumbled, resulting in acute shortages of basic household and consumer goods and the emigration of large sections of the population (Anarfi/Ofosu-Mensah/Ababio 2018). The ruling military government turned to the Libyan government under Muammar Gadhafi for badly needed support in terms of fuel, food and other essential items. This cemented the relationship between the two governments and led to the establishment of economic, military, social and educational exchanges between the two countries in 1983. The Libyan government also provided Ghana with military and technical training, and in exchange, Ghana paid with shipments of gold and other minerals. Technical exchanges between the two countries also resulted in the recruitment of Ghanaian English teachers, nurses, pharmacists, artisans and other unskilled labourers to Libya between 1983 and 1985 (Akyeampong 2000; Bob-Milliar/Bob-Milliar 2013; Kandilige/Hamidou 2019).

The conditions of service for Ghanaian expatriates in Libya were initially quite juicy. ${ }^{4}$ Ghanaian expatriates in Libya who visited home were the envy of many residents because they brought along all kinds of provisions, toiletries and home appliances which were either too expensive or not available in the country. Libya was the final destination for most Ghanaian migrants because, as one of our informants puts it, "it was not attractive to go elsewhere in those days, especially to Europe. People were living well in Libya and the cost of living was low. Everything was there - water, electricity, food and sometimes accommodation was provided by the company you worked for" (cf. Mensah 2012). News of the 'comfortable life' among Ghanaian expatriates in Libya quickly spread, resulting in several hundred more Ghanaians migrating to the country. Many of these were irregular migrants who had worked in

\footnotetext{
${ }^{3}$ Other ethnic groups in West Africa noted for their "passion" for migrating abroad include the Fulani and the Soninke of Mauretania and Senegal (cf. Tonah 2006; Rosenthal/Bahl/Worm 2017: 119; Fiedler 2018).

${ }^{4}$ According to our informants the cost of living in Libya was so low that they spent only half of their earnings on accommodation, food and other expenses. Ghanaian expatriates in Libya were allowed to transfer $50 \%$ of their earnings abroad, travel home on holiday once every two years and were allowed to bring their spouses to Libya under the family reunion programme as long as they had enough funds to support them. Furthermore, spouses of expatriates who had the required training and qualifications were allowed to work in Libya. Some of the Ghanaian expatriate workers took advantage of the favourable conditions to visit their friends and family members in the United Kingdom and elsewhere in Europe. According to one informant "it was easy to get a visa to Italy because of the strength of the Libyan economy while Southern Italy was a relatively poor region".
} 
Nigeria and Cote d'Ivoire in the 1970s and 1980s and decided to join the migration trail to Libya. Herein lies the beginning of Ghanaian irregular migration to Libya. ${ }^{5}$

Using the 'chain referral method', Ghanaians resident in Libya helped their extended family members, friends and town folks to travel irregularly to Libya for work. Returned migrants from Libya were at hand to serve as 'guides' providing persons willing to travel to Libya with guidelines on how to survive the journey across the desert, the safe routes to be used, the amount of money required as fares and bribes, and other survival tips. Many Ghanaians were in this way assisted to migrate to Libyan towns such as Tripoli, Sebha, Benghazi, Misurata, etc., where they worked for construction and electrical companies, in hospitals, as artisans (masons, carpenters, seamstresses, tailors, etc.) and labourers (cf. Codjoe 2017; Mensah 2012). ${ }^{6}$ In the mid-1980s following downturns in the Libyan economy and measures to privilege Libyan nationals for employment, there were several expulsions of 'illegal' Ghanaian migrants in Libya. Many of them were alleged to have been engaged in criminal activities, while others were rounded up by the Libyan authorities for not having work and/or resident permits. ${ }^{7}$

Between 1992 and 2003 the United Nations sanctions on Libya and the subsequent economic and political boycott of the country by Western governments further worsened an already deteriorating economy. As a result, the Gadhafi government initially intensified its pan-African policies and supported many sub-Saharan African countries with generous economic and development assistance. African migrants in Libya benefited from this policy change and were tolerated in the general society. However, the downturn in the country's economic fortunes affected the attitude of the indigenes towards migrants. Migrants were increasingly perceived to be too many and were accused of being privileged by the Gadhafi government. They were also blamed for the social ills of the country, such as petty thievery, prostitution, alcoholism, etc. The growing population of irregular migrants in the country compelled the Libyan government to tighten the visa requirements and institute border controls for Ghanaians and other West Africans travelling by land to that country (see Akyeampong 2000; Bob-Milliar 2012; Tonah/Setrana/Arthur 2017). The deteriorating social and economic situation in Libya compelled many migrants to seek

\footnotetext{
${ }^{5}$ Although often used interchangeably, we have used the term "irregular migration" instead of "illegal migration" because the former more appropriately captures the West African context where residents, travellers and migrants cross national borders without any form of documentation whatsoever. Such travels, though irregular, are not illegal. Illegal migration, on the other hand, typically occurs when persons move to a destination, usually a foreign territory, that they are by law not allowed to move to without permission. Illegal migrants may overstay their permits or use fake documents to travel and stay at their destinations (cf. De Haas 2008a).

${ }^{6}$ According to an informant, in the mid-1980s this phenomenon of irregular migration to Libya through the Sahara Desert was commonly referred to amongst the Ghanaian community in Libya as 'Mungo Park', in reference to the journeys of the English explorer of the Niger River in West Africa in the late $18^{\text {th }}$ century.

7 The Libyan authorities carried out intermittent raids on the migrant communities in the 1990s and those without the required documents were detained and later deported (cf. Pliez 2002, 2004; Hamood 2006).
} 
refuge in Europe (Bob-Milliar 2012; Hamood 2006; Bredeloup/Pliez 2011). When the UN sanctions against Libya were lifted in 2003, the government entered into a cooperation agreement with the European Union on migration which limited the use of Libya as a transit point for entry into the European Union. The EU-Libya Cooperation on Migration resulted in the further tightening of visa restrictions and border controls targeting migrants from West Africa.

\section{Irregular Migration from Nkoranza to Libya in the Post- Gadhafi Era (since 2012)}

In this section we present in detail the migration process from the Nkoranza area to Libya during the post-Gadhafi era. We describe the migration experiences of our respondents from the planning stage (which includes the decision-making process, mobilising funds, seeking information on the trip), their sojourn in the transit countries of Burkina Faso, Mali and Niger, contacts with family members en route and entry into Libyan territory. We relate this story largely from the perspectives of recently returned migrants (both forced and voluntary), members of the association of returned migrants (Borga Association), and extended family members of irregular migrants.

Based on information provided by the Borga Association, most (82 per cent) of those who travel to Libya are young males between the ages of 20 and 39 years. Only a few females have made the journey and they are mostly wives or siblings of migrants. This is mainly attributed to the hazardous nature of the trip. A vast majority of the irregular migrants were married (82 per cent), and had mainly Junior High School (71 per cent) education. Prior to their departure abroad, most of them (50 per cent) were engaged in farming or were artisans ( 20 per cent), the rest being traders, teachers and unemployed persons. This confirms the view that most irregular migrants were actually economically active before travelling abroad (cf. Codjoe 2017; Mensah 2012; Manuh 2011). The decision to travel by land to Libya was taken by the male migrants after consultations with their friends. Their wives and some extended family members often initially opposed such trips but had to accept the fait accompli after being unable to change the mind of their spouses and relatives. Most migrants received support (financial, moral and spiritual) from their wives, siblings and extended family members for the journey. More than 50 per cent of the migrants interviewed had earlier incurred huge debts from failed attempts to travel abroad regularly, while 30 per cent were victims of visa racketeers. The land route to Libya is preferred because it is cheaper, does not require having a travel document, can be done in stages, and migrants can work in the transit countries to accumulate funds before continuing their journey to Libya. A returned migrant told us that:

... when I was about to go I did not want my wife to know. I knew she will discourage me. However, I needed GHS 1,500 (U.S. \$500) in order to begin the journey. I had managed to get GHS 1,000 (\$333) and needed GHS 500 (\$166) more. I informed my 
wife who sells yam and goats. She wept and wept and tried discouraging me. She reported me to my brothers but they supported my intention. After they had agreed with me she had no option than to give me the rest of the money.

The journey to Libya is mainly done by public transport and usually takes several days but can last a few weeks in the case of difficulties. ${ }^{8}$ The migrants move in groups of four or five persons with a paid agent to assist them on the journey. The typical route takes them from Nkoranza through Bawku to Niamey (Niger). They then travel through the desert towns of Agadez in Niger, and Gathron and Sebha in Libya, until they arrive in Tripoli. ${ }^{9}$ Many migrants speak of harrowing experiences while travelling to Libya, particularly in the post-Gadhafi era. These include witnessing their companions die in the desert, being attacked and kidnapped by gangs, facing extortions from drivers and detentions by security personnel (cf. Tanle 2012).

Besides the Libyan citizens themselves, migrants from sub-Saharan Africa are amongst those who bear the brunt of the ongoing civil war in Libya. The insecurity created by the civil war resulted in a migration crisis affecting the over 1.5 million migrants in that country. Citizens from more than 120 countries were repatriated from Libya, with those from poor African countries suffering the most. About 790,000 migrants (out of which 212,331 were West Africans) fled Libya to the Sahelian countries to escape the war, while those trapped by fierce fighting had to be evacuated by their respective governments (Naik/Laczko 2012; Kleist 2017). For example, nearly 20,000 Ghanaians were evacuated from UNHCR and IOM centres in Libya in 2011. Flights were also organised by the Ghanaian government to evacuate persons who had fled across the Egyptian and Tunisian borders (Bob-Milliar 2012). Besides losing their jobs and livelihood, almost all Ghanaian returnees reported loss of their savings, forfeiture of salaries, loss of properties, equipment, businesses and other valuable items following their involuntary repatriation from Libya. Furthermore, sub-Saharan Africans including Ghanaians were targeted and detained by the rebel militias for allegedly supporting and fighting as mercenaries for the Gadhafi regime. They were subjected to attacks, abuse, robberies, unwarranted arrests, forced labour, torture, sexual abuse, extortion and slavery (Becker/Krause 2015; Kandilige/Hamidou 2019). Libyan youths also attacked migrants, particularly blacks from West and East Africa and were engaged in abuses, name-calling and other racist behaviour. One Ghanaian migrant told us that young Libyan girls in their community would hold their noses any time a black migrant passed by, indirectly indicating that the migrants were smelling. The black migrant population also

\footnotetext{
8 We also came across irregular migrants who spent several months on their way to Libya. This usually happens when they are robbed and get short of funds and have to work in the transit countries for several weeks and months before continuing their journey to Libya or other North African coastal destinations (cf. Rosenthal/Bahl/Worm 2017: 124 ff.).

${ }^{9}$ Almost all our informants used this route (that is, the Central Mediterranean route) through Libya to Italy. The two other routes are the Western Mediterranean route that goes through Mali, Algeria and Morocco to Ceuta and Melilla and ultimately Spain; and the Eastern Mediterranean route via Turkey to Greece (Codjoe 2017: 42; De Haas 2008a, 2008b). See the chapters of Fabio Santos, Arne Worm, and Christian Jorgow in this volume.
} 
suffered discrimination in Libyan society following the overthrow of Gadhafi. Many found it difficult to obtain accommodation, while others could no longer use the country's banking services (cf. Lucht 2012; Kleist 2017; Kandilige/Hamidou 2019).

Generally, the downturn in the economic fortunes of Libya, the civil unrest and political instability following the 2011 uprising, and the open hostilities towards migrants, particularly those from sub-Saharan Africa, compelled many migrants to risk their lives by crossing over to Europe (Bob-Milliar/Bob-Milliar 2013). Besides, the evacuation of nationals that followed the conflicts triggered a boom in the sea journey to Italy, with large numbers of migrants fleeing the civil war rather than returning to their countries of origin. This led to the emergence of facilitators and smugglers specialized in the business of clandestinely ferrying migrants from the Libyan coastal towns to Lampedusa and elsewhere in Italy on rickety boats and dinghies at cutthroat prices (see Hamood 2006). ${ }^{10}$ The possibilities of engaging the services of smugglers to cross over to Italy for a fee soon became public knowledge. Irregular migrants from Ghana also took advantage of the possibility of travelling to Europe. According to William Hanna, the European Union Ambassador to Ghana, some 4,114 Ghanaians arrived by boat in Italy in 2015, in 2016 the figure rose by 27 per cent to 5,636 .

\section{Impact of Irregular Migration on Left-Behind Family Members}

We have already indicated that most migrants were young, male and married. Only a few women accompanied their husbands or relations on this hazardous journey to Libya and Europe. Similarly, spouses and family members of the migrants opposed their decision to travel, although they could not dissuade them from undertaking the journey. A woman whose husband travelled irregularly to Europe related her experiences thus:

Well, I was afraid when my husband told me he wanted to travel [to Europe]. We had just married and before our marriage I had a child who was only two years old. Although I was afraid at first I gave him my help by going for money from my senior brother at Jema, around Kintampo. I knew that when he makes it in life I will surely benefit. Fortunately, the journey went well. Once a while he sends some money now. He finally crossed the sea and says that he is in a small town called Sicily (Adwoa, 26 years, Buabeng, May 2016).

Another person had this to say:

I was not in support of my brother's decision to travel. In fact, I still do not support it at all. Other family members were talking about me that I do not want my brother to make it in life so I am not in favour of him travelling abroad. When I told our mother

${ }^{10}$ Fees for the journey ranged between U.S. $\$ 1,000$ and 2,500 with many migrants making several attempts to reach Italy by boat (Hamood 2006; Mensah 2012). 
and uncles how dangerous it was they told me that many people have gone and they are making it in life. To avoid a bad name here in Yefri I immediately gave him GHS 2,000 for the trip. You see, what I said was true. Two years now and he always calls that it is not easy there. I have asked him to come to Yefri but he says he won't. He wants to do some more work in Benghazi where he is now. The kind of pain he is receiving from the work there is terrible (Kofi, 34 years, Yefri, May 2016).

The period after the departure for Libya and the migrant's first telephone call home is often characterized by anxiety, worries, sleeplessness and depression on the part of the left-behind family members, particularly the spouses. Most of the spouses informed us that they tried to deal with the situation by intensifying their religious activities, regular prayers, visits to friends and getting themselves busy. Generally, most migrants did not call home during the entire journey unless they desperately needed assistance, out of fear that this may destabilise their family members. They preferred to endure any suffering until they arrived at their final destination. This period could last between a few weeks and several months. The first telephone call by a migrant brings enormous relief to left-behind relatives. It was for many a sign that their relative was alive and not dead. News that their relation has finally arrived at his destination in Libya and found work or has successfully crossed the sea to Italy is often greeted with joy and thanksgiving to God.

Generally, persons with family members abroad are highly regarded and accorded much respect and prestige in the Nkoranza area. They are perceived to be wealthy even if they have not (yet) received any remittances from their family member abroad. They are expected to be generous and support the poor in their communities. Migration abroad is considered to be beneficial to the extended family of the migrant, as it is said to bring numerous economic, financial, social, educational and health benefits to the family members. This is because remittances received from abroad are used to support both the nuclear and extended family members, pay for food and household expenditure, school fees, health and medical bills, employ labourers on their farms and other forms of assistance. Large remittances are also used to set up businesses, purchase equipment and machinery, buy land and build a house (cf. Mazzucato/Kabki/Smith 2006). A parent who had just received remittances from one of his sons confirmed this to us:

When I meet my friends they tell me I have done well by supporting my sons to Libya so that they can travel to Europe. When we go anywhere like to funerals and they are introducing me they tell people that I have two sons and I have helped them travel to Libya so that they can go abroad. People respect me because my own junior brother too was financed by me in those days. Now he is in Holland. My brother respects me a lot. I even found a wife for him. Whatever I say he does it even more than what his wife says. He tells everyone from Busunya he meets in Holland to greet me when they come to Ghana. I feel proud about it. People come to me and ask how they can also travel although me myself I have not travelled outside before (Kwaku, 61 years, Busunya, May 2016). 
However, not all left-behind family members had positive experiences with their family members who migrated irregularly abroad. Some families had not heard from their migrant sons for a long period and presumed that they were dead. Others did not obtain any benefits from their migrant family member's sojourn abroad. Instead, they complained they had to contribute to bail out a family member who was being held hostage or in detention in Libya in what is often referred to as "reversed remittances" (cf. Mazzucato 2011; Adiku/Anamzoya 2018). Because most of the irregular migrants are young males, their departure leaves a huge gap in household demand for agricultural labour. A few families informed us that they had to hire labour to replace what their departed son would otherwise have provided on the farms, at home or in managing a business. Many respondents alluded to the fact that although they were highly regarded in the community their real economic status had not changed and they had not much to show for their son's stay abroad. One way in which irregular migration has impacted negatively on the social life of families left at home is the emotional trauma that the latter go through. This situation has led to some family members developing serious medical conditions such as hypertension, depression and insomnia, among others. A mother of an irregular migrant had this to say:

I always think about my son, where he is now and the condition he is in because I have heard so many stories about travelling using the Mediterranean. Although he is in Libya now, I am always worried that he might think of travelling to Europe using the sea. These kinds of thoughts coupled with his inability to properly take care of me has given me a lot of emotional trauma. I barely sleep without thinking of him. He is my only son and I am told he is in jail now (Akosua, 61 years, Fiema, June 2016).

Another respondent explained what she is going through as a result of the absence of the husband:

My husband is not having things easy where he is now. Every day I think of his current situation and what would be left of me and my sons when something bad happens to him.... We have two children under my care and on top of that I am taking care of his younger sister. My husband has been away for quite some time and as a woman I have needs. Sometimes I get the urge for sex, and one day I had to give in to another man. I feel very sad about it but I can't be blamed entirely. More so the children are not doing very well in school and I know it wouldn't be like this if he was here. I am not educated much and I am unable to supervise the studies of the children. If he was here he would help in that aspect. These are difficult times for me as a mother and wife whose husband is not around (Mary, 36 years, Fiema, June 2016).

The cases above illustrate some of the negative impacts of irregular migration on families left behind. The emotional trauma coupled with the many other responsibilities that spouses and relations have to undertake themselves because their family member is away bring a lot of psychological stress.

Quite a number of our respondents, particularly the wives of migrants, mentioned how the absence of their husbands is having a negative social impact on them 
and on the children. A few mentioned the fact that their children have been asking about the whereabouts of their fathers and they had to console them repeatedly by telling them that their fathers would be back soon. However, it appears the children expect to see their fathers in a number of days but these often turn out to be years. One effect of the long absence of fathers in the home is the breakdown or the nondevelopment of the emotional bonds between the migrant fathers and their children, even in situations where communication links with home were maintained through video calls and other means. Wives did tell us about the loneliness that they suffered as a result of having to live without their husbands for several years. Though the incidence of reported divorce was quite low, returned migrants who were divorced acknowledged the fact that their marriages broke down as a result of their long stay abroad and their inability to communicate regularly with their wives back home. The women informed us that they decided to abandon the marriage because they did not hear from their husbands for a long period of time and were not even sure their husbands were alive, given the many rumours about deaths in the desert and on the high sea.

Another issue frequently mentioned by left-behind wives was difficulties in accomplishing the household tasks singlehandedly. In the absence of their husbands they had to intensify their economic activities so that they could meet the financial requirements of the family. They also required time to do the day-to-day household activities like preparing meals for the family, taking the children to school, assisting them with their homework and taking them to the hospital in case of ill health. The performance of left-behind children in school was invariably negatively affected unless the family was able to get extra tuition for the children after school hours (cf. Codjoe 2017; Antman 2012; D'Emilio et al. 2007).

\section{Conclusions}

This paper has shown that migration to Libya has a long tradition in the Nkoranza area of Central Ghana. This tradition originated in the early 1980s when hundreds of skilled and unskilled Ghanaians emigrated to Libya following a technical cooperation agreement between the two countries. The downturn in the Libyan economy in the 1990s following the imposition of sanctions by the United Nations had adverse effects on the relation between the indigenes and migrants. Stiff border controls and visa regulations were imposed on new arrivals while West African migrants resident in Libya faced intermittent expulsions. The situation of migrants worsened after the overthrow of the Gadhafi regime in 2011. Violent conflicts and the fratricidal war that engulfed the country resulted in the evacuation of West African nationals from Libya while hundreds of foreign nationals fled the country. Libya has since been transformed from a major destination for Ghanaian and West African migrants into a transit country for irregular migration into Europe. 
The data confirms earlier studies which have shown that migration from the Nkoranza area to Libya and Europe is a popular way of improving individual and household livelihoods and of creating wealth, particularly among young male residents (cf. Manuh 2011; Codjoe 2017; Kleist 2017). However, residents are divided over the benefits of irregular migration. While returned migrants favour irregular migration abroad because it provides them with financial benefits, new skills, life experiences, personal sophistication and a different worldview that non-migrants do not have, their left-behind spouses and relatives consider the deprivations and risks involved in irregular migration to be too high and too numerous.

Two main factors explain why irregular migration to Libya and Europe remains popular in the Nkoranza area despite the huge risks involved. First, the individual migrant's assessment of the personal risk involved in the journey is low. This is a result of information provided by their "agents" and "travel guides", as well as friends and relatives in Libya, assuring them that there are oases of relative peace with availability of work in Libya. Secondly, it is due to the fatalistic attitude of individual migrants towards life, and the belief that each person has his fate, and that "if it is your destiny to make it (to Libya and Europe), it will definitely happen despite all odds". Many migrants therefore count themselves as being amongst those likely to be successful rather than being robbed, abused, killed, enslaved or left dying in the desert or the Mediterranean Sea.

The data indicates clearly that irregular migration has a very negative impact on the nuclear and extended family members left behind. Until a phone call or message comes in indicating that the migrant has arrived at his final destination safely, their spouses, parents and relatives remain on tenterhooks. They experience sleeplessness, irregular heartbeat, depression, trauma and other ailments. The (reported) death of a migrant en route to Libya or when crossing the Mediterranean is met with disbelief among left-behind family members. Long periods of separation between couples result in marital infidelity and divorce. Left-behind wives have to work extra hard to provide for themselves, their children and extended family members. This is a huge challenge especially when remittances are not (yet) forthcoming. Of course, irregular migration also has some positive benefits for the left-behind family members. Once remittances begin to arrive, the lives of left-behind family members change as they can afford better education and healthcare, establish a business, support extended family members and build a new home for the family. Left-behind family members enjoyed considerable prestige at home. Nevertheless, irregular migration remains a double-edged sword in the Nkoranza area.

Finally, our data shows that unlike other forms of transnational migration from Ghana which have become increasingly feminised (see Awumbila/Torvikeh 2018), irregular migration to Libya and Europe is largely a male dominated affair. The decision to migrate is made by the male member of the household after discussions with friends and peers, and often against the advice of their spouses and relatives. Nevertheless, spouses and relatives often contribute financially to the migrants' trip 
abroad, in the form of what are commonly referred to as "reverse remittances" (see Mazzucato 2011; Adiku/Anamzoya 2018).

Acknowledgments. We would like to thank the editors for several useful comments on an earlier version of this paper. We also benefited from suggestions made by an anonymous reviewer.

\section{References}

Adepoju, A. (ed.) (2010): International Migration Within, to and from Africa in a Globalised World. Accra: Sub-Saharan Publishers.

Adepoju, A. (2005): Patterns of Migration in West Africa. In: Manuh, T. (ed.): At Home in the World. International Migration and Development in Contemporary Ghana and West Africa. Accra: Sub-Saharan Publishers, 24-54.

Adiku, A. G./Anamzoya, A. (2018): Patriarchal Norms in Reverse Remittance Behaviour among Ghanaian Transnational Couples. In: Awumbila, M./Badasu, D./Teye, J. (eds.): Migration in a Globalizing World. Perspectives from Ghana. Accra: Sub-Saharan Publishers, 206-222.

Agyeman, E. A./Setrana, M. B. (2014): Human Mobility in Ghana. In: Baggio, F. (ed.): Africans on the Move. Human Mobility in Ghana, Nigeria, Angola and South Africa. Cape Town: Scalabrini Institute for Human Mobility in Africa, 13-70.

Akyeampong, E. (2000): Africans in the Diaspora. The Diaspora and Africa. In: African Affairs, 99, 183-215.

Anarfi, J./Kwankye, S. (2003): Migration from and to Ghana. A Background Paper. DRC on Migration, Globalization and Poverty. Sussex: University of Sussex.

Anarfi, K. J./Ofosu-Mensah, E./Ababio, E. (2018): A Historical Perspective of Migration from and to Ghana. In: Awumbila, M./Badasu, D./Teye, J. (eds.): Migration in a Globalising World. Perspectives from Ghana. Accra: SubSaharan Publishers, 51-71.

Antman, F. M. (2012): The Impact of Migration on Family Left Behind.

Discussion Paper Series. Forschungsinstitut zur Zukunft der Arbeit. No. 6374. Online: http://nbn-resolving.de/urn:nbn:de:101:1-201206146492 $<03.11 .2016>$.

Arthur, A. J. (2008): The African Diaspora in the United States and Europe. The Ghanaian Experience. London: Ashgate. 
Awumbila, M./Manuh, T./Quartey, P./Antwi Bosiakoh, T./Tagoe, C. A. (2011):

Migration and Mobility in Ghana. Trends, Issues and Emerging Research

Gaps. Accra: Woeli Publishing Services.

Awumbila, M./Torvikeh, G. D. (2018): Women on the Move. An Historical

Analysis of Female Migration in Ghana. In: Awumbila, M./Badasu, D./Teye, J.

(eds.): Migration in a Globalizing World. Perspectives from Ghana. Accra:

Sub-Saharan Publishers, 171-189.

Becker, J. M./Krause, U. (2015): Flucht und ihre Ursachen. Netzwerk

Fluchtforschung. Online: https://blog.fluchtforschung.net/flucht-und-ihreursachen $/<08.04 .2020>$.

Bob-Milliar, G. M. (2012): Rescuing Migrants in Libya. The Political Economy of State Response to Migration Crisis. The Case of Ghana. DIIS Working Paper No. 16, Copenhagen, Denmark.

Bob-Milliar, G. M./Bob-Milliar, R. (2013): The Politics of Trans-Saharan Transit Migration in the Maghreb. Ghanaian Migrants in Libya, c. 1980-2012. In: African Review of Economics \& Finance, 5(1), 60-73.

Bredeloup, S./Pliez, O. (2011): The Libyan Migration Corridor. Robert Schuman Center for Advanced Studies, European University Institute, Florence, Italy.

Codjoe, O. E. (2017): The Impact of Irregular Migration into Europe through the Mediterranean on the Social Life of Families in the Nkoranza North District of Ghana. MPhil Thesis, Department of Sociology, University of Ghana, Legon.

D’Emilio, A. L./Cordero, B./Bainvel, B./Skoog, C./Comini, D./Gough, J./Kilbane, T. (2007): The Impact of International Migration. Children Left Behind in Selected Countries of Latin America and the Caribbean. New York: United Nations Children's Fund (UNICEF).

De Haas, H. (2008a): Irregular Migration from West Africa to the Maghreb and the European Union. An Overview of Recent Trends. Geneva: International Organization for Migration.

De Haas, H. (2008b): The Myth of Invasion. The Inconvenient Realities of African Migration to Europe. In: Third World Quarterly, 29(7), 1305-1322.

Fiedler, A. (2018): Migration from Sub-Saharan Africa to Europe. Reasons, Sources of Information and Perception of German Engagement. Stuttgart: Institut für Auslandsbeziehungen.

Ghana Statistical Service (GSS) (2014): 2010 Population and Housing Census.

District Analytical Report. Nkoranza North District, Nkoranza.

Hamood, S. (2006): African Transit Migration through Libya to Europe. The Human Cost. Cairo: American University of Cairo. 
Kandel, W./Massey, D. S. (2002): The Culture of Mexican Migration. A Theoretical and Empirical Analysis. In: Social Forces, 80(3), 981-1004.

Kandilige L./Hamidou, M. N. (2019): Migrants in Countries in Crisis. The Experiences of Ghanaian and Nigerien Migrants during the Libyan Crisis of 2011. In: African Human Mobility Review, 5(2), 1583-1610.

Kleist, N. (2017): Disrupted Migration Projects. The Moral Economy of Involuntary Return to Ghana from Libya. In: Africa, 87(2), 322-342.

Lucht, H. (2012): Darkness before Daybreak. African Migrants Living on the Margins in Southern Italy Today. Berkeley: University of California Press.

Manuh, T. (ed.) (2005): At Home in the World. International Migration and Development in Contemporary Ghana and West Africa. Accra: Sub-Saharan Publishers.

Manuh, T. (2011): Assessment of Libyan Returnees in the Brong Ahafo Region. Report Presented at UNCT and NADMO, Accra.

Massey, D. S. (2012): Contemporary Theories of International Migration. In: Massey, D. S./Arango, J./Hugo, G./Kouaouci, A./Pellegrino, A./Taylor, J. E. (eds.): Worlds in Motion. Understanding International Migration at the End of the Millennium. Oxford: Clarendon Press, 17-59.

Mazzucato, V. (2011): Reverse Remittances in the Migration-Development Nexus. Two-Way Flows between Ghana and the Netherlands. In: Population, Space and Place, 17, 454-468.

Mazzucato, V./Kabki, M./Smith, L. (2006). Locating a Ghanaian Funeral. Remittances and Practices in a Transnational Context. In: Development and Change, 37(5), 1047-1072.

Mensah, E. A. (2012): The Saga of the Returnee. Exploring the Implications of Involuntary Return Migration for Development. A Study of the Reintegration Process for Ghanaian Migrant Workers from Libya. Master thesis in Development Management, University of Agder, Kristiansand.

Naik, A./Laczko, F. (2012): The Bittersweet Return Home. Forced Migration Review 39. Online: www.fmreview.org/north-africa/naik-laczko.html $<05.08 .2016>$.

Pliez, O. (2002): Vieux reseaux et nouvelles circulations entre les deux rives du sahara. In: Revue Mediterannee, 3/4, 31-34.

Pliez, O. (2004): De l'immigration au transit? La Libye, dans l'espace migratoire Euro-Africain. In: Pliez, O. (ed.): La nouvelle Libye. Sociétés, espaces et géopolitique au lendemain de l'embargo. Paris: Kathala, 138-155. 
Rosenthal G./Bahl, E./Worm, A. (2017): Illegalized Migration Courses From the Perspectives of Biographical and Figurational Sociology. The Land Border between Spain and Morocco. In: Rosenthal, G./Bogner, A. (eds.) (2017): Biographies in the Global South. Life Stories Embedded in Figurations and Discourses. Frankfurt a. M./New York: Campus, 103-159.

Tanle, A. (2012): Everybody Has His or Her Luck. Irregular Migration of Young People from Ghana to Libya and Beyond. In: Journal of Arts and Social Science, 1, 43-46.

Tonah, S. (2006): Fulani in Ghana. Migration History, Integration and Resistance. Accra: Yamens Publishers Ltd.

Tonah, S. (2007): Ghanaians Abroad and Their Ties Home. Cultural and Religious Dimensions of Transnational Migration. Centre on Migration, Citizenship and Development (COMCAD) Working Paper No. 25, Faculty of Sociology, University of Bielefeld, Bielefeld, Germany.

Tonah, S./Setrana, M. B./Arthur, J. (eds.) (2017): Migration and Development in Africa. Trends, Challenges and Policy Implications. Lanham/Boulder/New York/London: Lexington Books. 